\section{Búzalisztek minőségének becslése tészta nyújtás-szakítás alapján állományvizsgáló múszerrel}

\author{
Horváthné Almássy Katalin ${ }^{1}$ - Ács Péterné ${ }^{2}$ - \\ Baráné Herczegh Ottilia ${ }^{1}$ - Deák Anita ${ }^{1}$ \\ ${ }^{1}$ Szegedi Tudományegyetem, Élelmiszeripari Főiskolai Kar, \\ Szeged \\ ${ }^{2}$ Gabonatermesztési Kutató Kht., Szeged
}

\section{ÖSSZEFOGLALÁS}

Irodalmi tapasztalatok figyelembevételével módszert dolgoztunk ki a QTS25 állományvizsgáló készülékre extenzográf analóg tésztavizsgálatra. Jelen munkánkban 54, a Szegedi Gabonatermesztési Kutató Kht. fajtafenntartó kisérleteiböl származó fajtaazonos búzalisztmintát vizsgáltunk meg az eljárással. Tanulmányoztuk, hogy módszerünk alkalmas lehet-e a hagyományos minősitéssel (próbasütés, farinográfos vizsgálat, sikérvizsgálat) kapott eredmények becslésére.

Megállapítottuk, hogy a QTS25 mikroextenzográfos adatok közül a nyújtási ellenállás (Hardness), a nyújtási munka (Area) értékek szoros, szignifikáns kapcsolatban vannak a sütőipari értékszám és a sikérterülés adatokkal. Szintén erōsen szignifikáns a nyújtási értékszám (BC/AC) és a vizfelvevőképesség kapcsolata. Ezek az összefüggések tökéletesen egyeznek az elözö kisérletsorozatunkban, ipari lisztminták esetében tapasztaltakkal. Valamennyi QTS25 mikroextenzográfos adat és a MININFRA módszerrel meghatározott szemkeménység között is szoros, szignifikáns korreláció mutatkozott. Korábbi eredményeinkkel szemben, jelen mintasorozatunkban nem találtunk közvetlen kapcsolatot a QTS25 adatok és a cipójellemzök között.

Lépésenkénti változószelekció segítségével, több változó bevonásával javult a sütőipari értékszám becslése mikroextenziós adatokkal. A cipótérfogat szignifikáns becslését szintén lépésenkénti változószelekció segitségével QTS25 és MININFRA adatok bevonásával sikerült megoldani.

\section{SUMMARY}

Literature experience was utilised to develop a method for the extensograph analog testing of paste with a QTS25 Texture Analyser. 54 wheat flour samples from the same variety from variety-preservation experiments at the Szeged were tested with this method. A study was made to establish whether the method is suitable for the estimation of results derived by traditional classification (trial baking, farinograph and gluten tests).

A close and significant correlation was found between the hardness and area data measured with a QTS25 microextensograph, the farinograph values and the gluten spreading data, and also between the stretching index $(B C / A C)$ and the water uptake capacity. These correlations correspond well with the findings from a previous experimental series on industrial flour samples. A close and significant correlation was likewise observed between the grain hardness established by the MININFRA method and all the QTS25 micro-extensograph data. In contrast with earlier QTS25 data, however a close correlation was not found between the QTS25 data and the loaf characteristics.

With the use of micro-extensograph data, the estimation of the baking industry value has been improved through stepwise variable selection, with the inclusion of several variables. The estimation of loaf volume could also be solved by means of stepwise variable selection with the inclusion of QTS25 and MININFRA data.

\section{PROBLÉMAFELVETÉS, CÉLKITÜZÉS}

A 90-es években Magyarországon is fokozatosan háttérbe szorult a mennyiségorientált termelés és ismét megnőtt a minőségre koncentrált nemesítés jelentősége. A fajták minősítésére, a megfelelőek kiszürése számos vizsgálati módszert alkalmaznak. A sütő és malomipari gyakorlatban alkalmazott vizsgálati módszerek miniatürizált változatai különösen hasznos segítséget nyújtanak a nemesítőknek a fajtakiválasztásnál

A kenyérbúzák mellett egyéb sütőipari célra, pl. kekszgyártásra, pizzatésztához stb. is nemesítenek ma már búzafajtákat. Utóbbiaknak más a minőségi igénye, s ez a tény is új vizsgálati módszereket igényel.

A tésztareológia gyakorlati szempontból leginformatívabb vizsgálati módszere a farinográfos vizsgálat, mely a tészta kialakulás jellege mellett a tészta dagasztástürő képességére ad felvilágosítást. A kész tészta formázása illetve kelesztése során alapvető jelentősége van a viszkoelasztikus tésztaszerkezetért felelős sikérváz reológiai viselkedésének, ezért funkcionális szempontból mind a nedves sikért mind pedig a tésztát a nyújthatósággal, azaz a szakadási hosszal és a nyújtási ellenállással is jellemezhetjük.

A különféle müszeres nyújtási-szakítási módszerek (laborográf, extenzográf, alveográf stb.) a nyújtási (út-erő) diagram adatait használják fel a lisztminőség jellemzésére. E célműszerek hátránya, hogy csak az adott vizsgálat végzésére alkalmasak. A 80-as évektől egyre inkább terjed a többcélú állományvizsgáló készülékekhez (pl.: Instron, TaXT2) tervezett speciális vizsgáló fejek alkalmazása tészta és nedves sikér nyújtási és szakítási viselkedésének nyomonkövetésére.

SZTE Élelmiszeripari Főiskolai Karán rendelkezésünkre álló QTS25 állományvizsgáló készülékhez mi is kifejlesztettünk egy búzatészták mikroextenziós vizsgálatára alkalmas eszközt. Folytatva korábbi munkánkat (Horváth-Almássy és mtsai, 2001), ebben a sorozatunkban fajtaazonos búzalisztek bevonásával tanulmányoztuk, hogy a müszer segítségével nyert mikroextenziós adatok hogyan hozhatók kapcsolatba a hagyományos sütőipari jellemzőkkel (farinogramból nyerhető adatok, nedves sikér tulajdonságok, próbasütés eredménye). 


\section{AZ QTS 25 NYÚJTÁSI DIAGRAM}

A QTS25 állományvizsgáló müszer elsődleges célja az állományprofilanalízis (TPA), valamint az anyag viselkedésének nyomonkövetése húzó illetve nyomó igénybevétel hatására. A mérési körülményeket (mérőfej mozgatási sebessége, a vizsgálat során megtett út, a vizsgáló fej formája, anyaga stb.) a vizsgáló személy határozza meg a minta tulajdonságainak ismeretében. A mérés elve a tészta regisztrált nyújtása és szakítása tenzió üzemmódban. A próbatestben a nyújtási deformáció hatására ébredő ellenállás erö-út(idő) függvény a GRUZL-féle laborogramhoz és a BRABENDER-féle extenzogramhoz hasonló lefutású, ezért értelmezése is hasonló módon történik (1. ábra).

1. ábra: QTS tésztanyújtási diagrammok

(I. jól nyújtható, normál erősségü sikérü tészta,

II. lágy, gyenge minőségű sikérü tészta)

Súly, $g(1)$

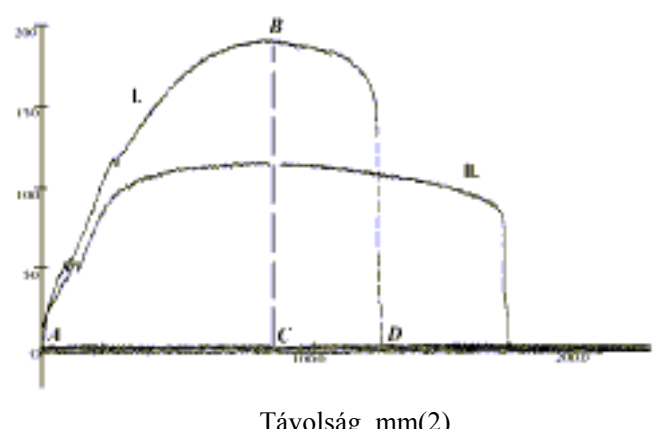

Figure 1: The QTS Dough strech diagrams (I. good extensible dough with normal strong gluten, II. dough with soft and low grade gluten)

Load, $\mathrm{g}(1)$, Distance, $\mathrm{mm}(2)$
A görbe alatti terület (ABD; Area; gs) a nyújtáshoz és szakításhoz szükséges munka. A görbe magassága (BC; Hardness; g) a nyújtási ellenállás. A nyújthatóság vagy maximális nyúlás az $\mathrm{AC}$ szakasz hossza mm-ben. A görbéröl leolvasható még a teljes szakadási hossz is ( $\mathrm{AD} ; \mathrm{mm})$. A nyújtási ellenállás és a nyújthatóság hányadosaként értelmezhető nyújtási értékszám (NYÉSZ ${ }_{\mathrm{QTS}} ; \mathrm{g} / \mathrm{mm}$ ). A szakadási értékszám (SZÉSZ $\left.\mathrm{QTS}_{\mathrm{Q}} ; \mathrm{g} / \mathrm{mm}\right)$ a nyújtási ellenállás és a szakadási hossz hányadosa:

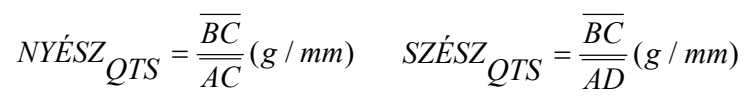

\section{VIZSGÁLATI MINTÁK ÉS MÓDSZEREK}

A vizsgálatokhoz Szegedi Gabonatermesztési Kht. Fajtafenntartó kísérleteiből származó 54 fajtaazonos lisztmintát használtunk (30 db Szegedről és $24 \mathrm{db}$ Táplánszentkeresztről). A mintákat a Kutatóintézet Lisztlaboratóriumában őröltük meg BL55 minőségüre. A szokásos sütőipari minősítést, kiegészítve a MININFRA sikér és szemkeménység vizsgálattal, a Gabonatermesztési Kutató Kht. Lisztlaboratóriumában végeztük.

A QTS25 mikroextenziós méréseket az SZTE Szegedi Élelmiszeripari Főiskolai Karán hajtottuk végre. A GRUZL-féle laborográf alapján kialakított klasszikus extenzográfos tésztavizsgálati módszert Kieffert és mtsai (1981), valamint Li és mtsai (1997) tapasztalatainak figyelembevételével adaptáltuk készülékünkre. Házilag terveztük meg és készítettük el az alkalmas tésztabefogó fejet, a vizsgálati próbatest formázásához szükséges tésztaprést, valamint Lásztity (1966) nyomán a $30 \mathrm{~g}$ liszt dagasztására alkalmas kézi dagasztóberendezést $(2$. ábra).

2. ábra: Mikroextenziós tésztavizsgálat QTS25 állományvizsgálóval: A) dagasztás; B) formázás; C) vizsgálat

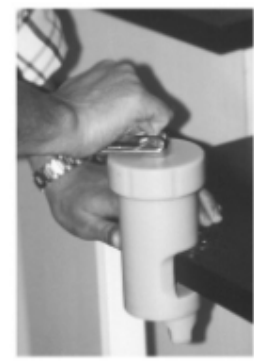

A)

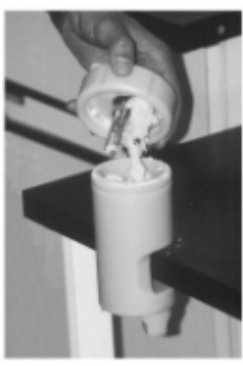

B)

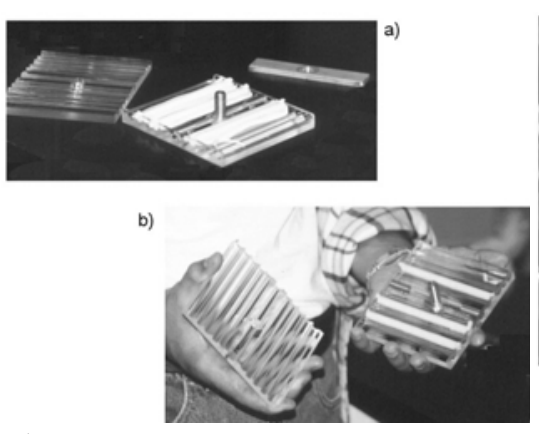

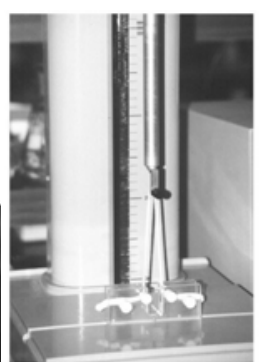

Nyújtás(1)

C)

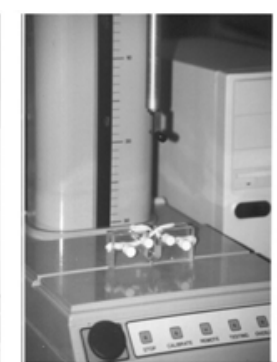

Szakítás(2)

Figure 2: Microextension dough examination with QTS 25 Textur analyser: A) Kneading; B) Forming; C) Examination Stretching(1), Tearing(2)

A vizsgálandó tésztaidom előállítását előző mintasorozatunk (Horváth-Almássy és mtsai, 2001) tapasztalatainak figyelembevételével a következők szerint módosítottuk: $30 \mathrm{~g}$ lisztet beletöltöttünk az asztalhoz rögzített, kézi dagasztóba. $16 \mathrm{~cm}^{3} 2 \%$
NaCl-t tartalmazó desztillált vizet töltöttünk a liszthalom közepében kialakított mélyedésbe. A dagasztóvillával egybeszerelt tetőt felhelyeztük és a kézi dagasztókart 90 másodperc alatt 120-szor körülforgatva, a tésztát megdagasztottuk. A 
tésztadarabot 10 gömbölyítő mozdulattal kis gombóccá formáltuk. A mintát zárt térben, $30^{\circ} \mathrm{C}$-on 20 percig pihentettük, majd kézi sodrással kb. $32 \mathrm{~cm}-$ es hengerré nyújtottuk és $4 \mathrm{db} 8 \mathrm{~cm}$-es darabra vágtuk. A csíkokat az erre a célra készített, $30^{\circ} \mathrm{C}$-ra előmelegített plexi tésztaprésbe helyeztük. A prést a mintával együtt 20 percig tovább termosztáltuk. Méréskor a mindkét végén rögzített tésztahengert a közepén beakasztott horoggal szakítottuk el, 200 $\mathrm{mm} /$ perc sebességü húzással.

\section{VIZSGALATI ÉRTÉKELÉS̈̈K \\ EREDMÉNYEK}

ÉS

Munkánk során kapott eredeti adatok statisztikai jellemzőit az 1. táblázat mutatja.

A hagyományos sütőipari vizsgálatokból és a QTS25 extenzogramból nyert eredmények korrelációs mátrixából a szignifikáns kapcsolatban álló jellemzőket a 2. a.-2. c. táblázat tartalmazza. Megállapítható, hogy a QTS25 extenzogramból nyert adatok többsége, mind termőhelyenként, mind pedig a teljes mintapopulációra vonatkozóan, egymással szignifikáns kapcsolatban van. Ezzel szemben a hagyományos sütőipari jellemzők egymás közötti és a QTS25 jellemzőkhöz való korrelációja a két mintacsoporton belül eltérő. A szegedi minták esetében lényegesen jobb. Ez valószínüleg termőhelyi hatásra is utal.

A teljes mintacsoportra $(n=54)$ vonatkozó korrelációs mátrixból (2. c. táblázat) látható, hogy a QTS25 mikroextenzográfos adatok a hagyományos vizsgálati módszerekkel kapott adatok közül elsősorban a farinográfos értékszámmal, a sikérterüléssel valamint a farinográfos vízfelvevő képességgel állnak szignifikáns kapcsolatban. Ez a megfigyelés a tésztakészítés bizonyos módosítása ellenére (desztillált víz helyett $2 \%$-os $\mathrm{NaCl}$ oldatot használtunk és a mintákat $2 \times 20$ percig pihentettük $30^{\circ} \mathrm{C}$-on $2 \times 15$ perc helyett) egyezik a korábbi mintasorozatunknál ${ }^{1}$ tapasztaltakkal. Ez azt jelenti, hogy a sikérterülés és a sütőipari értékszám erősen szignifikánsan korrelál a Hardness (BC) és az Area (görbe alatti terület) QTS értékekkel, a vízfelvevő képesség pedig a nyújtási értékszámmal (BC/AC). Ezzel szemben a cipóadatok ebben a mintapopulációban közvetlenül nem becsülhetök QTS25 adatokkal. Érdekes megjegyezni, hogy a szemkeménység szinte minden QTS25 értékkel korrelál.

A sütőipari értékszám és a sikérterülés regressziós egyenesét és becslő egyenletét QTS25 adatokkal a 3. és a 4. ábra tartalmazza.

Megvizsgáltuk a továbbiakban, hogy a QTS25 extenzogram adatainak és a gyors vizsgálati eredményt adó MININFRA módszer adatainak egyidejü figyelembevételével, többszörös lineáris regressziós egyenlettel javulhat-e a farinográfos értékszám illetve a cipótérfogat becslése. Lépésenkénti változószelekcióval az 5. és a 6. ábrán látható eredményeket kaptuk.

A két termőhelyről származó mintapopulációnk vizsgálati eredményeiből megállapítottuk, hogy a QTS25 mikroextenzográfos adatok közül a nyújtási ellenállás (Hardness), a nyújtási munka (Area) értékek szoros, szignifikáns kapcsolatban vannak a sütőipari értékszám és a sikérterülés adatokkal. Szintén erősen szignifikáns a nyújtási értékszám (BC/AC) és a vízfelvevő képesség kapcsolata. Ezek az összefüggések tökéletesen egyeznek az előző kísérletsorozatunkban, ipari lisztminták esetében tapasztaltakkal. Ezen túlmenően valamennyi QTS25 mikroextenzográfos adat és a MININFRA módszerrel meghatározott szemkeménység között is szoros, szignifikáns korreláció mutatkozott.

Egyes fontos sütőipari adatok becslésére tehát a QTS25 tésztanyújtási jellemzők alkalmasak, mivel az adatok között szignifikáns a kapcsolat. További vizsgálatok szükségesek az eredmények megerősítésére és többek között a termőhely-hatás vizsgálatára a módszerrel kapcsolatban.

\section{IRODALOM}

Horváth-Almássy K.-Győri-Mile I.-Bara-Herczegh O.-Szabó B. (2001): Mikroextenzográfos tésztavizsgálat QTS25 állományvizsgálóval. Sütőipar, XLVIII. 1. 42-46.

Kieffer, R.-Kim, J. J.-Belitz, H. D. (1981): Zugversuche mit Weizenkleber im Mikromaßstab. Zeitschrift für Lebensmitteluntersuchung und -forschung 172. 190-192.

Lásztity, R. (1966): Élelmiszeripari speciális gyakorlatok. BME egyetemi jegyzet, Tankönyvkiadó, Budapest

Li, X.-Gras, W. P.-Mares, D. J. (1997): A Comparison of twogram and ten-gram mixigraphs for measurement of mixing properties in soft wheats. Cereal'97, Proceeding of the $47^{\text {th }}$
Australian cereal Chemistry Conference held in Perth, $14^{\text {th }}$ to $18^{\text {th }}$ september, 1997 (Ed. By A. V. Tarr; A. S. Ross and C. W. Wrigley) National Library of Australia, Canberra, 232234.

Li, X.-Gras, W. P-Mares, D. J. (1997): Comparison of dough properties of soft Wheats from northern NSW and WA using a small scale extension test. Cereal'97, Proceeding of the $47^{\text {th }}$ Australian cereal Chemistry Conference held in Perth, $14^{\text {th }}$ to $18^{\text {th }}$ september, 1997 (Ed. By A. V. Tarr; A. S. Ross and C. W. Wrigley) National Library of Australia, Canberra, 228231 . 
A mintapopuláció jellemzőinek statisztikája az összes adatra (Szeged, Táplánszentkereszt, n=54)

\begin{tabular}{|c|c|c|c|c|c|c|c|c|c|c|c|c|c|c|c|c|c|}
\hline & $\begin{array}{c}\text { Hard } \\
\text { (BC) } \\
(\mathrm{g})\end{array}$ & $\begin{array}{c}\text { Area } \\
\text { (gs) }\end{array}$ & $\begin{array}{c}\text { AD } \\
(\mathbf{m m})\end{array}$ & $\begin{array}{c}\mathrm{AC} \\
(\mathrm{mm})\end{array}$ & $\begin{array}{l}\text { BC/AD } \\
(\mathrm{g} / \mathrm{mm})\end{array}$ & $\begin{array}{l}\text { BC/AC } \\
(\mathrm{g} / \mathrm{mm})\end{array}$ & $\begin{array}{c}\text { Kiőrlés } \\
\text { (\%) } \\
(1)\end{array}$ & $\begin{array}{c}\text { Nsikér } \\
\text { (\%) } \\
(2)\end{array}$ & $\begin{array}{c}\text { Szsikér } \\
(\%) \\
(3)\end{array}$ & $\begin{array}{c}\text { Sik.ter. } \\
(\mathbf{m m}) \\
(4)\end{array}$ & $\begin{array}{c}\text { Vízfelv. } \\
\text { (\%) } \\
(5)\end{array}$ & $\begin{array}{c}\text { Farin. } \\
\text { érték } \\
\text { (6) }\end{array}$ & $\begin{array}{c}\text { Cipó } \\
\text { térf. } \\
\left(\mathrm{cm}^{3}\right) \\
(7)\end{array}$ & $\begin{array}{c}\text { Alaki } \\
\text { hány. } \\
\text { (8) }\end{array}$ & $\begin{array}{c}\text { Nsikér } \\
\text { infra } \\
(\%) \\
(9) \\
\end{array}$ & $\begin{array}{c}\text { Szkem. } \\
\text { infra } \\
(10)\end{array}$ & $\begin{array}{c}\text { Eséssz. } \\
\text { (sec) } \\
(11)\end{array}$ \\
\hline ÁTL. & 179,1 & 7140 & 177 & 143 & 1,1 & 1,4 & 60,6 & 30,5 & 10,1 & 4,3 & 56,4 & 73,3 & 956,6 & 2,2 & 32,1 & 54 & 341,5 \\
\hline MIN. & 80,6 & 3399 & 118 & 66 & 0,4 & 0,5 & 51,0 & 22,2 & 7,5 & 0,5 & 49,9 & 39,5 & 766,0 & 1,8 & 25,6 & 30 & 78,0 \\
\hline MAX. & 343,0 & 13450 & 250 & 250 & 2,3 & 3,1 & 68,7 & 45,5 & 14,6 & 11,3 & 64,3 & 100,0 & 1219,0 & 3,4 & 43,7 & 87 & 499,0 \\
\hline
\end{tabular}

Jelölések(12):

Kiőrlés(1), Nedves sikér(2), Száraz sikér(3), Sikér terülés(4), Vízfelvevő képesség(5), Farinográfos értékszám(6), Cipótérfogat(7), Alaki hányados(8), Nedves sikér, MININFRA(9), Szemkeménység, MININFRA(10), Esésszám(11)

Table 1: Statistic of the summarized data (Szeged, Táplánszentkerest, $n=54$ )

Extraction(1), Wet gluten content(2), Dry gluten content(3), Gluten spreading(4), Water capacity(5), Farinograph value(6), Loaf volume(7), Shape quotient of the loaf(8), Wet gluten, MININFRA(9), Grain hardness, MININFRA(10), Falling number(11), Labels(12)

Szignifikáns korrelációk az extenziós, farinográfos, sikér és cipó adatok között (Szeged, n=30)

\begin{tabular}{|c|c|c|c|c|c|c|c|c|c|c|c|c|c|c|c|}
\hline & Hard & Area & AD & $\mathrm{AC}$ & BCAD & BCAC & $\begin{array}{c}\text { Nsikér } \\
\text { (1) }\end{array}$ & $\begin{array}{l}\text { Sikérter. } \\
\text { (2) } \\
\end{array}$ & $\begin{array}{c}\text { Vífelv. } \\
\text { (3) }\end{array}$ & $\begin{array}{c}\text { Farin. ért. } \\
\text { (4) }\end{array}$ & $\begin{array}{c}\text { Cipó térf. } \\
\text { (5) }\end{array}$ & $\begin{array}{c}\text { Alakih. } \\
\text { (6) }\end{array}$ & $\begin{array}{c}\text { Nsikér inf. } \\
(7) \\
\end{array}$ & \begin{tabular}{|c|}
$\begin{array}{c}\text { Szkem. inf. } \\
(8)\end{array}$ \\
\end{tabular} & $\begin{array}{c}\text { Esészz. } \\
\text { (9) }\end{array}$ \\
\hline Hard & 1 & $\begin{array}{l}0,8416 \\
0,0000\end{array}$ & $\begin{array}{c}-0,5160^{* *} \\
0,0030\end{array}$ & & $\begin{array}{c}0,9339 * * * \\
0,0000\end{array}$ & $\begin{array}{c}0,8423 * * * \\
0,0000\end{array}$ & $\begin{array}{l}0,0175 \\
0,9253\end{array}$ & $\begin{array}{c}-0,5756^{* * *} \\
0,0007\end{array}$ & $\begin{array}{c}0,5792 * * * \\
0,0006\end{array}$ & $\begin{array}{c}0,6652 * * * \\
0,0000\end{array}$ & & & & $\begin{array}{c}0,4358^{*} \\
0,0143\end{array}$ & \\
\hline Area & & 1 & $\begin{array}{l}-0,0010 \\
0,9957\end{array}$ & & $\begin{array}{c}0,6029 * * * \\
0,0003\end{array}$ & $\begin{array}{c}0,4492 * \\
0,0113\end{array}$ & & $\begin{array}{c}-0,6381^{* * *} \\
0,0001\end{array}$ & $\begin{array}{c}0,3884 * \\
0,0308\end{array}$ & $\begin{array}{c}0,6471 * * * \\
0,0001\end{array}$ & & & & & $\begin{array}{c}0,4582^{*} \\
0,0095\end{array}$ \\
\hline AD & & & 1 & $\begin{array}{c}0,8977^{* * *} \\
0,0000\end{array}$ & $\begin{array}{c}-0,7575^{* * *} \\
0,0000\end{array}$ & $\begin{array}{c}-0,8257^{* * *} \\
0,0000\end{array}$ & & & $\begin{array}{c}-0,4333^{*} \\
0,0149\end{array}$ & & & & & & \\
\hline $\mathrm{AC}$ & & & & 1 & $\begin{array}{c}-0,5572^{* *} \\
0,0011\end{array}$ & $\begin{array}{c}-0,7023^{* * *} \\
0,0000\end{array}$ & & & $\begin{array}{c}-0,3729 * \\
0,0388\end{array}$ & & & & & & \\
\hline BCAD & & & & & 1 & $\begin{array}{c}0,9692 * * * \\
0,0000\end{array}$ & & $\begin{array}{c}-0,4022^{*} \\
0,0249\end{array}$ & $\begin{array}{c}0,5776^{* * *} \\
0,0007\end{array}$ & $\begin{array}{c}0,5437 \text { ** } \\
0,0016\end{array}$ & & & & $\begin{array}{l}0,3908^{*} \\
0,0297\end{array}$ & \\
\hline BCAC & & & & & & 1 & & & $\begin{array}{c}0,5646^{* * *} \\
0,0009\end{array}$ & $\begin{array}{c}0,4582^{* *} \\
0,0095\end{array}$ & & & & & \\
\hline Nsikér & & & & & & & 1 & & $\begin{array}{c}0,5033^{* *} \\
0,0039\end{array}$ & & $\begin{array}{c}0,5720 * * * \\
0,0008\end{array}$ & & $\begin{array}{c}0,8520 * * * \\
0,0000\end{array}$ & $\begin{array}{c}0,4032^{*} \\
0,0245\end{array}$ & \\
\hline Sikérter. & & & & & & & & 1 & & $\begin{array}{c}-0,6782 * * * \\
0,0000\end{array}$ & & & & & $\begin{array}{c}-0,4888^{* *} \\
0,0053\end{array}$ \\
\hline Vízfelv. & & & & & & & & & 1 & $\begin{array}{c}0,5195 * * \\
0,0027\end{array}$ & $\begin{array}{c}0,5047 * * \\
0,0038\end{array}$ & & $\begin{array}{c}0,4850^{* *} \\
0,0057\end{array}$ & $\begin{array}{c}0,7326^{* * *} \\
0,0000\end{array}$ & \\
\hline Farin. ért. & & & & & & & & & & 1 & & & & $\begin{array}{l}0,2524 \\
0,1708\end{array}$ & $\begin{array}{c}0,5154^{* *} \\
0,0030\end{array}$ \\
\hline Cipó térf. & & & & & & & & & & & 1 & $\begin{array}{c}-0,4321^{*} \\
0,0152\end{array}$ & $\begin{array}{c}0,5459 * * \\
0,0015\end{array}$ & $\begin{array}{c}0,6260^{* * *} \\
0,0002\end{array}$ & \\
\hline Alakih. & & & & & & & & & & & & 1 & $\begin{array}{l}0,1165 \\
0,5325\end{array}$ & & \\
\hline Nsikér inf. & & & & & & & & & & & & & 1 & $\begin{array}{c}0,4376^{*} \\
0,0138\end{array}$ & \\
\hline Szkem. inf. & & & & & & & & & & & & & & 1 & \\
\hline Eséssz. & & & & & & & & & & & & & & & 1 \\
\hline
\end{tabular}

Jelölések(10):

Nedves sikér(1), Sikér terülés(2), Vízfelvevő képesség(3), Farinográfos értékszám(4), Cipótérfogat(5), Alaki hányados(6), Nedves sikér,

MININFRA(7), Szemkeménység, MININFRA(8), Esésszám(9)

$*<0,05$, a kapcsolat szignifikáns(11), $* *<0,01$, a kapcsolat erősen szignifikáns(12), ***<0,001, a kapcsolat igen erősen szignifikáns(13)

A korrelációs koefficiensek alatti sor a valószínüségi szintet (p) mutatja(14)

Table 2. a: Significant correlations between Extension, Farinogram, Gluten and Loaf data (Szeged, $n=30)$

Wet gluten content(1), Gluten spreading(2), Water capacity(3), Farinograph value(4), Loaf volume(5), Shape quotient of the loaf(6), Wet gluten, MININFRA(7), Grain hardness, MININFRA(8), Falling number(9), Labels(10)

$*<0,05$, the relation is significant(11), **<0,01, the relation is rather strongly significant(12), ***<0,001, the relation is very strongly significant(13), The row under the correlation coefficients shows the probability level(14) 
Szignifikáns korrelációk az extenziós, farinográfos, sikér és cipó adatok között (Táplánszentkereszt, n=24)

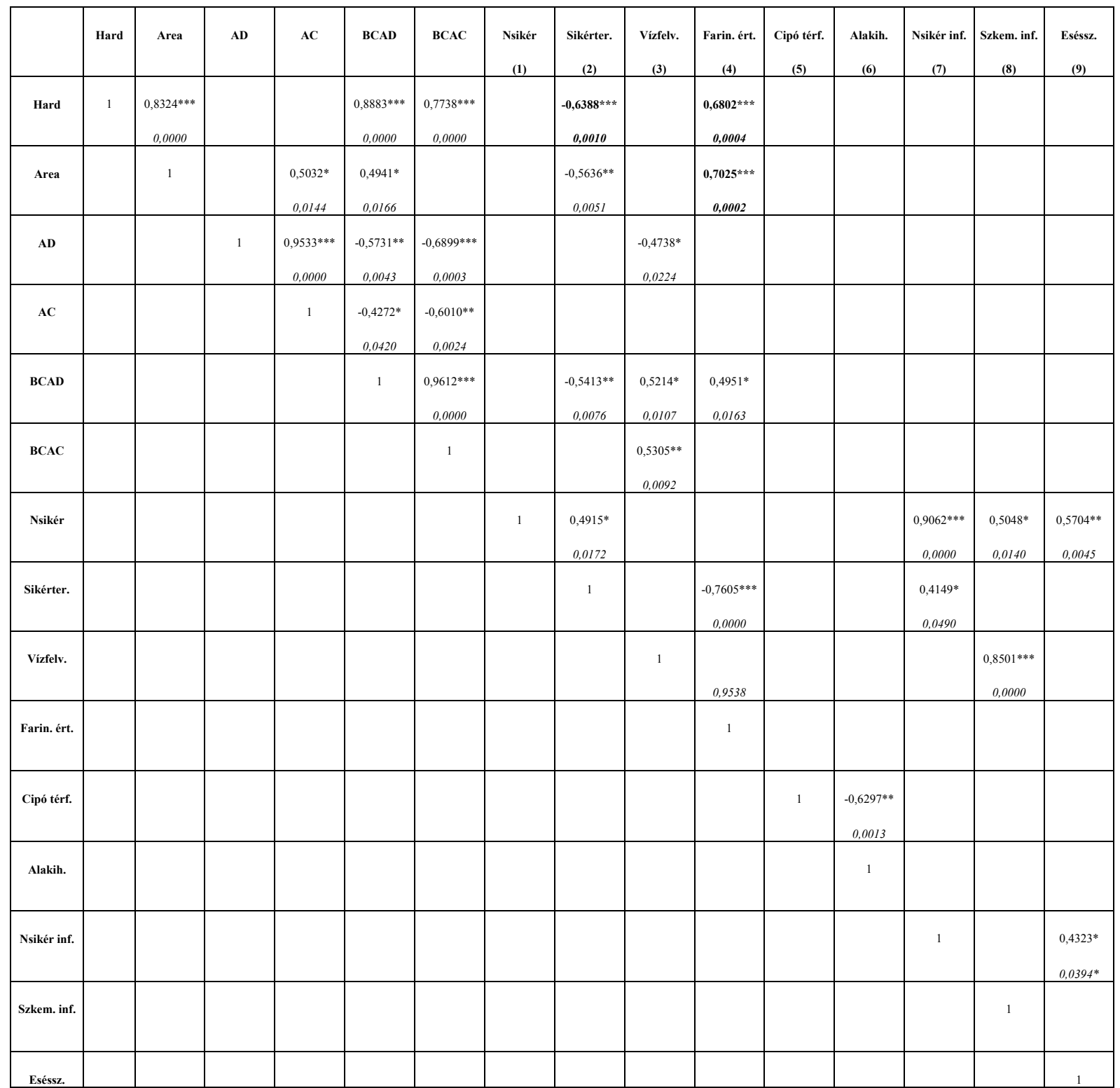

Jelölések(10):

Nedves sikér(1), Sikér terülés(2), Vízfelvevő képesség(3), Farinográfos értékszám(4), Cipótérfogat(5), Alaki hányados(6), Nedves sikér, MININFRA(7), Szemkeménység, MININFRA(8), Esésszám(9)

$*<0,05$, a kapcsolat szignifikáns(11), $* *<0,01$, a kapcsolat erősen szignifikáns(12), $* * *<0,001$, a kapcsolat igen erősen szignifikáns(13)

A korrelációs koefficiensek alatti sor a valószínüségi szintet (p) mutatja(14)

Table 2. b: Significant correlations between Extension, Farinogram, Gluten and Loaf data (Táplánszentkereszt, $n=24)$

Wet gluten content(1), Gluten spreading(2), Water capacity(3), Farinograph value(4), Loaf volume(5), Shape quotient of the loaf(6), Wet gluten, MININFRA(7), Grain hardness, MININFRA(8), Falling number(9), Labels(10)

$*<0,05$, the relation is significant $(11), * *<0,01$, the relation is rather strongly significant $(12)$, $* * *<0,001$, the relation is very strongly significant(13), The row under the correlation coefficients shows the probability level(14) 
Szignifikáns korrelációk az extenziós, farinográfos, sikér és cipó adatok között (összes adat, n=54)

\begin{tabular}{|c|c|c|c|c|c|c|c|c|c|c|c|c|c|c|c|}
\hline & Hard & Area & AD & $\mathrm{AC}$ & BCAD & BCAC & $\begin{array}{c}\text { Nsikér } \\
\text { (1) } \\
\end{array}$ & $\begin{array}{c}\text { Sikérter. } \\
\text { (2) } \\
\end{array}$ & $\begin{array}{c}\text { Vízfelv. } \\
\text { (3) } \\
\end{array}$ & $\begin{array}{c}\text { Farin. ért. } \\
\text { (4) } \\
\end{array}$ & $\begin{array}{c}\text { Cipó térf. } \\
\text { (5) }\end{array}$ & $\begin{array}{c}\text { Alakih. } \\
\text { (6) } \\
\end{array}$ & \begin{tabular}{|c|} 
Nsikér inf. \\
$(7)$ \\
\end{tabular} & \begin{tabular}{|c} 
Szkem. inf. \\
$(8)$ \\
\end{tabular} & $\begin{array}{c}\text { Eséssz. } \\
\text { (9) }\end{array}$ \\
\hline Hard & 1 & $\begin{array}{c}0,7903^{* * *} \\
0,0000 \\
\end{array}$ & $\begin{array}{c}-0,3237^{*} \\
0,0170 \\
\end{array}$ & & $\begin{array}{c}0,9026^{* * * *} \\
0,0000 \\
\end{array}$ & $\begin{array}{c}0,7959 * * * * \\
0,0000 \\
\end{array}$ & & $\begin{array}{c}-0,5832^{* * *} \\
0,0000 \\
\end{array}$ & $\begin{array}{c}0,4362^{* * *} \\
0,0010 \\
\end{array}$ & $\begin{array}{c}0,6478^{* * * *} \\
0,0000 \\
\end{array}$ & & & & $\begin{array}{c}0,3389 * * \\
0,0122 \\
\end{array}$ & \\
\hline Area & & 1 & $\begin{array}{l}0,2877 * \\
0,0349 \\
\end{array}$ & $\begin{array}{c}0,4573^{* * * *} \\
0,0005 \\
\end{array}$ & $\begin{array}{c}0,4627^{* * *} \\
0,0004 \\
\end{array}$ & $\begin{array}{l}0,3019^{*} \\
0,0265 \\
\end{array}$ & & $\begin{array}{c}-0,5647^{* * * *} \\
0,0000 \\
\end{array}$ & $\begin{array}{l}0,3251^{*} \\
0,0164 \\
\end{array}$ & $\begin{array}{c}0,6541 * * * \\
0,0000 \\
\end{array}$ & & & & & \\
\hline AD & & & 1 & $\begin{array}{c}0,9357^{* * *} \\
0,0000 \\
\end{array}$ & $\begin{array}{c}-0,6692 * * * \\
0,0000 \\
\end{array}$ & $\begin{array}{c}-0,7607^{* * *} \\
0,0000 \\
\end{array}$ & & & & & & & & $\begin{array}{c}-0,3396^{*} \\
0,0120 \\
\end{array}$ & \\
\hline AC & & & & 1 & $\begin{array}{c}-0,4943^{* * * *} \\
0,0001 \\
\end{array}$ & $\begin{array}{c}-0,6459 * * * \\
0,0000 \\
\end{array}$ & & & & & & & & $\begin{array}{r}-0,2878^{*} \\
0,0348 \\
\end{array}$ & \\
\hline BCAD & & & & & 1 & $\begin{array}{c}0,9661 * * * \\
0,0000\end{array}$ & & $\begin{array}{c}-0,4241 * * \\
0,0014 \\
\end{array}$ & $\begin{array}{c}0,4192 * * \\
0,0016 \\
\end{array}$ & $\begin{array}{c}0,4798^{* * *} \\
0,0002 \\
\end{array}$ & & & & $\begin{array}{c}0,3752 * * \\
0,0052 \\
\end{array}$ & \\
\hline BCAC & & & & & & 1 & & $\begin{array}{c}-0,2978^{*} \\
0,0287 \\
\end{array}$ & $\begin{array}{c}0,3904 * * \\
0,0035 \\
\end{array}$ & $\begin{array}{c}0,3649 * * \\
0,0067 \\
\end{array}$ & & & & $\begin{array}{c}0,3530^{* *} \\
0,0088 \\
\end{array}$ & \\
\hline Nsikér & & & & & & & 1 & $\begin{array}{l}0,2905^{*} \\
0,0331 \\
\end{array}$ & & & $\begin{array}{l}0,3084^{*} \\
0,0233 \\
\end{array}$ & & $\begin{array}{c}0,8622^{* * * *} \\
0,0000 \\
\end{array}$ & $\begin{array}{c}0,4873^{* * *} \\
0,0002\end{array}$ & \\
\hline Sikérter. & & & & & & & & 1 & $\begin{array}{r}-0,2282 \\
0,0969\end{array}$ & $\begin{array}{c}-0,7023^{* * *} \\
0,0000 \\
\end{array}$ & $\begin{array}{l}-0,0531 \\
0,7028 \\
\end{array}$ & & & & \\
\hline Vizfelv. & & & & & & & & & 1 & $\begin{array}{c}0,3513^{* *} \\
0,0092 \\
\end{array}$ & $\begin{array}{l}0,3187^{*} \\
0,0188 \\
\end{array}$ & & & $\begin{array}{c}0,5953^{* * *} \\
0,0000\end{array}$ & $\begin{array}{r}0,2836^{*} \\
0,0377\end{array}$ \\
\hline Farin. ért. & & & & & & & & & & 1 & & & & & $\begin{array}{l}0,3365^{*} \\
0,0129 \\
\end{array}$ \\
\hline Cipó térf. & & & & & & & & & & & 1 & $\begin{array}{c}-0,5354^{* * *} \\
0,0000 \\
\end{array}$ & $\begin{array}{c}0,3828^{* *} \\
0,0043 \\
\end{array}$ & $\begin{array}{c}0,3871^{* *} \\
0,0038 \\
\end{array}$ & \\
\hline Alakih. & & & & & & & & & & & & 1 & & & \\
\hline Nsikér inf. & & & & & & & & & & & & & 1 & $\begin{array}{c}0,4297 * * \\
0,0012 \\
\end{array}$ & \\
\hline
\end{tabular}

Jelölések(10):

Nedves sikér(1), Sikér terülés(2), Vízfelvevő képesség(3), Farinográfos értékszám(4), Cipótérfogat(5), Alaki hányados(6), Nedves sikér, MININFRA(7), Szemkeménység, MININFRA(8), Esésszám(9)

*<0,05, a kapcsolat szignifikáns(11), $* *<0,01$, a kapcsolat erősen szignifikáns(12), ${ }^{*} * * 0,001$, a kapcsolat igen erősen szignifikáns(13) A korrelációs koefficiensek alatti sor a valószínüségi szintet (p) mutatja(14)

Table 2. c: Significant correlations between Extension, Farinogram, Gluten and Loaf data (Whole data, $n=54)$

Wet gluten content(1), Gluten spreading(2), Water capacity(3), Farinograph value(4), Loaf volume(5), Shape quotient of the loaf(6), Wet gluten, MININFRA(7), Grain hardness, MININFRA(8), Falling number(9), Labels(10)

$*<0,05$, the relation is significant $(11), * *<0,01$, the relation is rather strongly significant(12), ***<0,001, the relation is very strongly significant(13), The row under the correlation coefficients shows the probability level(14) 
3. ábra: A sütőipari értékszám becslése QTS25 „Hardness” (nyújtási ellenálás) adatokkal $(\mathrm{SE} \%=17,54)$

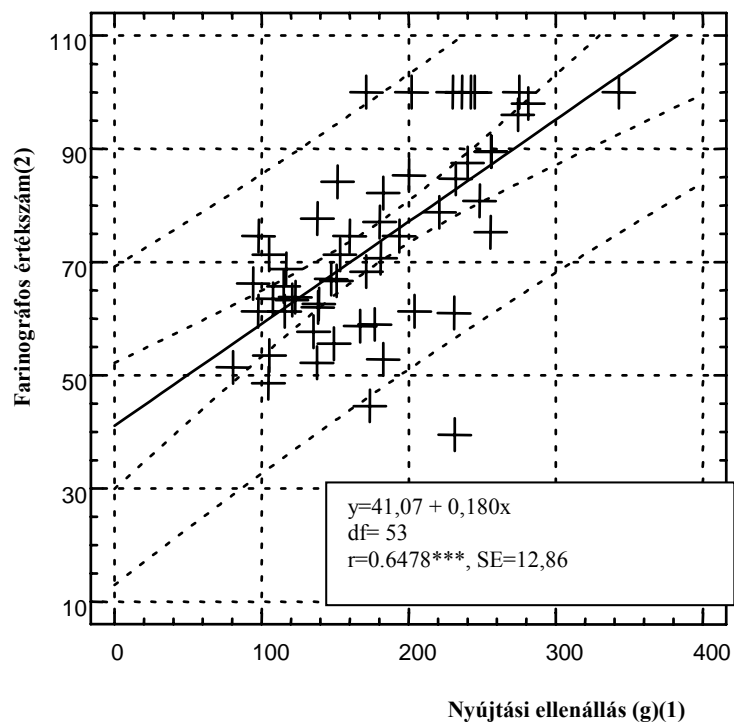

Figure 3: Estimation of Farinograf value with QTS25 Hardness data $(S E \%=17,54)$

Hardness (g)(1), Farinograph value(2)

5. ábra: A mért és a QTS25 adatokkal becsült farinográfos értékszám regressziója $(\mathrm{SE} \%=16,4)$

(Az egyenletben $X_{H}$ Hardness (nyújtási ellenállás); $X_{\mathrm{AD}}$ szakadási hossz)

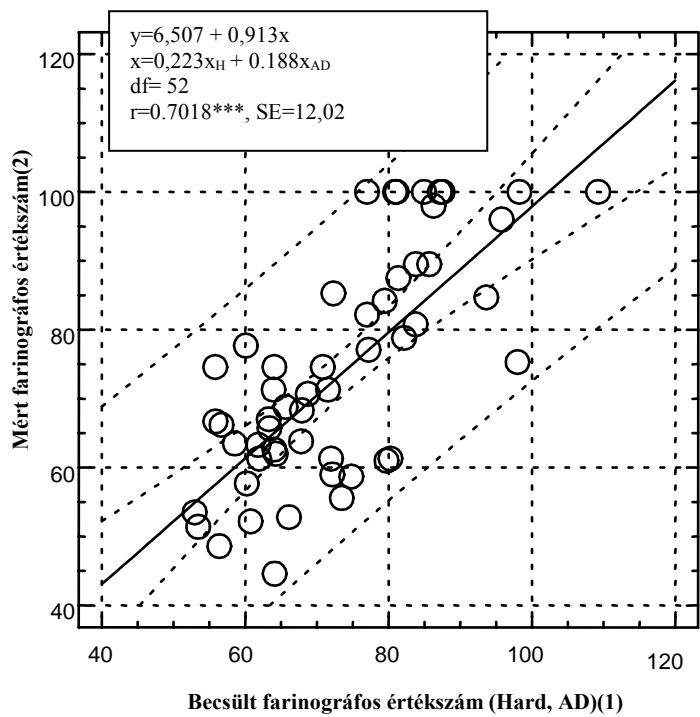

Figure 5: Regression between observed farinograf value and with the QTS25 data estimated farinograf value $\left(X_{H}\right.$ Hardness; $X_{A D}$ Distance of breaking)

Estimated farinograph value (Hard, AD)(1), Observed farinograph value(2)
4. ábra: A sikérterülés becslése QTS25 „Hardness” (nyújtási ellenállás) adatokkal $(\mathrm{SE} \%=41,9)$

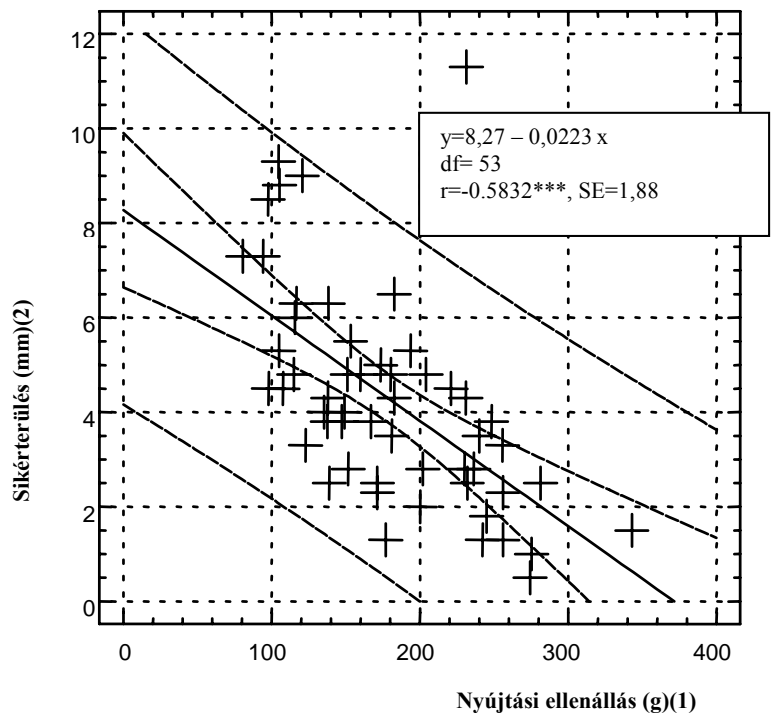

Figure 4: Estimation of gluten spreading data with QTS25 Hardness data $(S E \%=41,9)$

Hardness (g)(1), Gluten stretching (mm)(2)

6. ábra: A mért és a QTS25 valamint MININFRA adatokkal becsült cipótérfogat értékek regressziója $(\mathrm{SE} \%=\mathbf{9}, 88)$

(Az egyenletben $X_{H}$ Hardness (nyújtási ellenállás); $X_{\mathrm{si}}$ MININFRA készülékkel meghatározott nedves sikér tartalom)

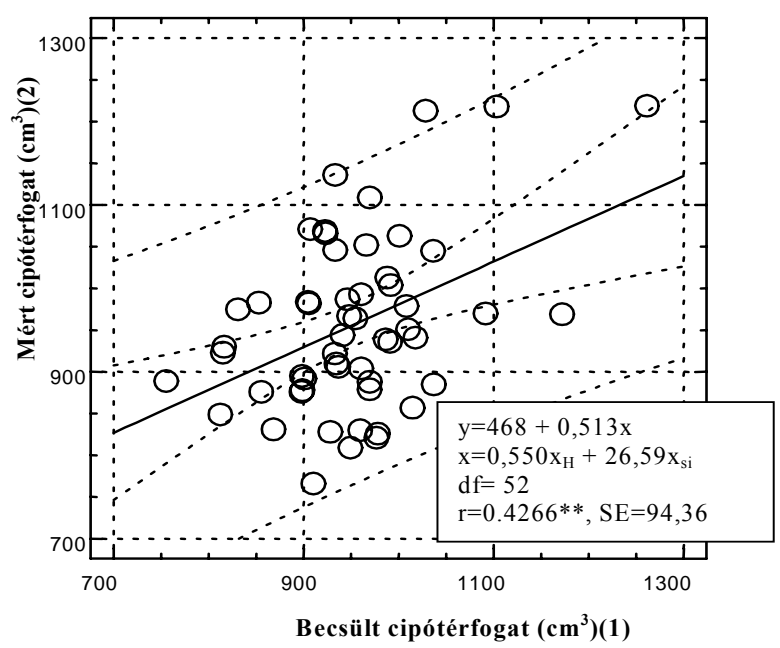

Figure 6: Regression between observed loaf volume and with QTS25 and MININFRA data estimated loaf volume $(S E \%=9,98)$ $\left(X_{H}\right.$ Hardness; $X_{s i}$ MININFRA moisture gluten content) Estimated loaf volume $\left(\mathrm{cm}^{3}\right)(1)$, Observed loaf volume $\left(\mathrm{cm}^{3}\right)(2)$ 